\title{
The Fe Protein: An Unsung Hero of Nitrogenase
}

\author{
Andrew J. Jasniewski, Nathaniel S. Sickerman, Yilin $\mathrm{Hu}$ * and Markus W. Ribbe * \\ Department of Molecular Biology and Biochemistry, University of California, Irvine 2236/2448 McGaugh Hall, \\ Irvine, CA 92697-3900, USA; ajasniew@uci.edu (A.J.J.); nsickerm@uci.edu (N.S.S.) \\ * Correspondence: yilinh@uci.edu (Y.H.); mribbe@uci.edu (M.W.R.); Tel.: +(0)1-949-824-4615 (Y.H.); \\ +(0)1-949-824-9509 (M.W.R.)
}

Received: 7 December 2017; Accepted: 29 January 2018; Published: 3 February 2018

\begin{abstract}
Although the nitrogen-fixing enzyme nitrogenase critically requires both a reductase component (Fe protein) and a catalytic component, considerably more work has focused on the latter species. Properties of the catalytic component, which contains two highly complex metallocofactors and catalyzes the reduction of $\mathrm{N}_{2}$ into ammonia, understandably making it the "star" of nitrogenase. However, as its obligate redox partner, the Fe protein is a workhorse with multiple supporting roles in both cofactor maturation and catalysis. In particular, the nitrogenase Fe protein utilizes nucleotide binding and hydrolysis in concert with electron transfer to accomplish several tasks of critical importance. Aside from the ATP-coupled transfer of electrons to the catalytic component during substrate reduction, the Fe protein also functions in a maturase and insertase capacity to facilitate the biosynthesis of the two-catalytic component metallocofactors: fusion of the $\left[\mathrm{Fe}_{8} \mathrm{~S}_{7}\right] \mathrm{P}$-cluster and insertion of Mo and homocitrate to form the matured [(homocitrate) $\mathrm{MoFe}_{7} \mathrm{~S}_{9} \mathrm{C}$ ] M-cluster. These and key structural-functional relationships of the indispensable Fe protein and its complex with the catalytic component will be covered in this review.
\end{abstract}

Keywords: nitrogenase; NifDK; NifH; MoFe; Fe protein; reductase; maturase; metalloprotein

\section{Introduction}

The enzyme molybdenum (Mo)-nitrogenase is capable of facilitating the biological fixation of atmospheric dinitrogen into bioavailable nitrogen sources at ambient temperature and pressure [1] in the following reaction:

$$
\mathrm{N}_{2}+8 \mathrm{e}^{-}+16 \mathrm{MgATP}+8 \mathrm{H}^{+} \rightarrow 2 \mathrm{NH}_{3}+\mathrm{H}_{2}+16 \mathrm{MgADP}+16 \mathrm{P}_{\mathrm{i}}
$$

where ATP is adenosine triphosphate, $\mathrm{ADP}$ is adenosine diphosphate, and $\mathrm{P}_{\mathrm{i}}$ is inorganic phosphate.

The catalytic enzyme component that is responsible for the $\mathrm{N}_{2}$ reduction activity in Azotobacter vinelandii is the gene product NifDK, which is commonly known as the MoFe protein. NifDK is an $\alpha_{2} \beta_{2}$ tetramer that houses two sets of complex metallocofactors: an [ $\left.\mathrm{Fe}_{8} \mathrm{~S}_{7}\right]$ cofactor known as the P-cluster and a [ $\mathrm{MoFe}_{7} \mathrm{~S}_{9} \mathrm{C}$-homocitrate] cofactor called the M-cluster (Figure 1). The P-cluster is involved in electron mediation for the M-cluster, which is the site of nitrogen fixation, and both clusters are critical for enzyme reactivity. In addition to NifDK, catalysis by the enzyme requires a reductase component called $\mathrm{NifH}$ (or Fe protein), which is a homodimeric protein that contains a $\left[\mathrm{Fe}_{4} \mathrm{~S}_{4}\right]$ cluster and nucleotide binding sites [2]. 


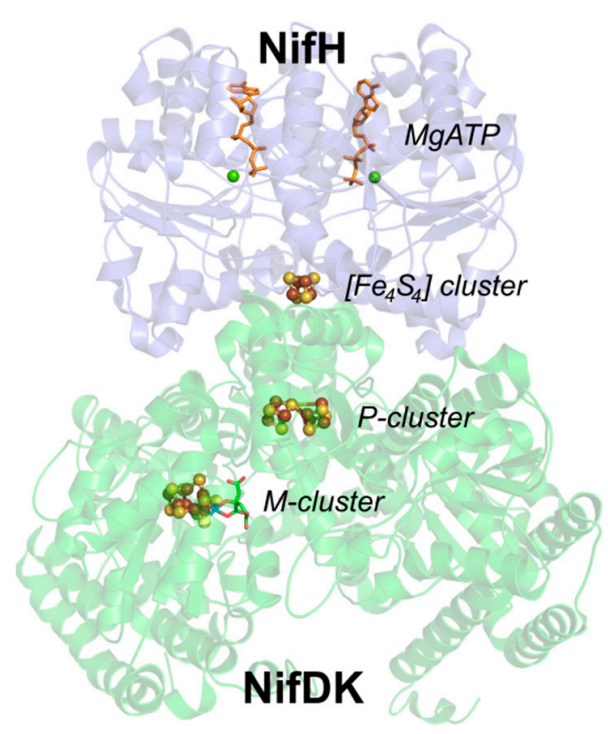

Figure 1. Crystal structure of the complex of NifDK (bottom, green) and NifH (top, purple) with MgATP bound (PDB code 1G12) [3], showing the relative position of the metallocofactors and nucleotides. For clarity, only one half of the symmetrical complex is shown.

During normal catalytic turnover conditions, the reduced, nucleotide-bound Fe protein binds to NifDK, leading to the transfer of an electron from the reductase component $\left[\mathrm{Fe}_{4} \mathrm{~S}_{4}\right]$ cluster to the interfacial P-cluster of the catalytic component (Figure 1). The electron transfer process is intimately tied to nucleotide hydrolysis (see Section 3), which in turn leads to dissociation of NifH from NifDK. The dynamic complex association and dissociation occurs multiple times until enough electrons have been delivered from $\mathrm{NifH}$, via the P-cluster on NifDK, to the catalytic component active site, i.e., the M-cluster. The Fe protein is rather unique, because it facilitates important reactions in the nitrogenase maturation process in addition to the reductase function during catalytic turnover [4-7], and these will be discussed below.

In addition to the Mo-containing nitrogenase, there exist variants that substitute the Mo with $\mathrm{V}$ (known as VFe protein) or Fe (known as FeFe protein) in the catalytic cluster [8]. These "alternative" nitrogenase species have assembly proteins that differ from the Mo-nitrogenase system, including variants of the Fe protein: $\mathrm{VnfH}$ for the VFe protein and $\mathrm{AnfH}$ for the FeFe protein. In many respects, these Fe proteins are nearly identical, but they carry out selective incorporation of the apical heteroatom $(\mathrm{Mo}, \mathrm{V})$ into their respective nitrogenase clusters.

This review will focus on describing the function and structure of the Fe protein, which is an essential part of nitrogenase assembly and catalysis. Additionally, this review follows the mechanism of M-cluster biosynthesis as outlined in ref. [9]; however, an alternative cofactor biosynthesis mechanism can be found in ref. [7] and the citations therein.

\section{The Roles of the Fe Protein}

The Fe protein is a multi-purpose actor in the process of nitrogen fixation and metallocofactor assembly. To date, there are three primary recognized functions: (1) Mo and homocitrate insertase for the maturation of an $8 \mathrm{Fe}$ precursor to the M-cluster; (2) reductase to facilitate P-cluster formation on NifDK; and (3) essential electron transfer partner to NifDK for nitrogen fixation catalysis. The attribution of these functions to the Fe protein is best illustrated by strains of $A$. vinelandii that have had the gene encoding for nifH deleted [5]. These $\Delta$ nifH mutant strains express a NifDK that (1) completely lacks the M-cluster and (2) possesses an unmatured precursor of the P-cluster (designated the $\mathrm{P}^{*}$-cluster). Furthermore, $\Delta$ nifH strains (3) cannot fix nitrogen, although the catalytic activity can be rescued by addition of purified $\mathrm{NifH}$ to crude cell extracts. The main functions of NifH within Mo-nitrogenase are elaborated upon below. 


\subsection{Mo and Homocitrate Insertase}

The Fe protein of Mo-nitrogenase participates in what is considered both the "in situ" and "ex situ" maturation of the NifDK cofactors, meaning that cofactor maturation occurs either on NifDK (in the case of P-cluster) or outside the protein (in the case of M-cluster), respectively. As stated above, deletion of nifH from wild-type Mo-nitrogenase produces a variant of NifDK that is devoid of the M-cluster [5]. This finding implicates NifH in the "ex situ" construction of the M-cluster, which involves several FeS-containing assembly proteins that eventually lead to the insertion of M-cluster into the cofactor-deficient (apo)-NifDK. The particular role of NifH within the "ex situ" biosynthesis of the M-cluster is now firmly established, with the protein intercepting the assembly pathway at the scaffold protein NifEN and delivering Mo and homocitrate to a cofactor precursor [9]. However, many details are unclear about the transformation.

The protein NifEN is homologous to NifDK and binds a precursor to the catalytic cofactor, an $\left[\mathrm{Fe}_{8} \mathrm{~S}_{9} \mathrm{C}\right]$-core cluster that is designated the L-cluster [10]. Although the crystallography of NifEN is limited to a single structure [11], the protein exists as a heterotetramer containing a $\left[\mathrm{Fe}_{4} \mathrm{~S}_{4}\right]$ cluster located at a position analogous to the P-cluster of NifDK, with the L-cluster sequestered in the $\alpha$ subunit. Biochemical maturation studies with NifEN have shown that in order to mature the bound L-cluster to the M-cluster, the following components, at minimum, must be incubated with this protein: dithionite, $\mathrm{NifH}, \mathrm{MgATP}$, molybdate $\left(\mathrm{MoO}_{4}{ }^{2-}\right)$, and $R$-homocitrate [12]. This incubation mixture unambiguously leads to accumulation of the M-cluster on NifEN, as established by electron paramagnetic resonance (EPR) and X-ray absorption spectroscopic (XAS) studies [13]. The gene product NifQ has also been proposed to play a role in Mo trafficking and incorporation into the M-cluster [14]; however, NifQ is non-essential for in vitro M-cluster biosynthesis [4].

Importantly, the necessity of nucleotide in the process suggests that ATP hydrolysis is required for cluster maturation. Consistent with this assessment, the omission of MgATP from the incubation mixture or the use of NifH mutants that are incapable of ATP hydrolysis do not produce matured M-cluster on NifEN [12]. Based on the homology between NifEN and the catalytic component NifDK, $\mathrm{NifH}$ is proposed to bind to the former protein and form a transient complex analogous to the complex formed with the latter protein (See Section 3.2). Once complexed to NifEN, the transfer of Mo and homocitrate from $\mathrm{NifH}$ to the bound L-cluster is proposed to occur, leading to a displacement of one Fe atom from the $\left[\mathrm{Fe}_{8} \mathrm{~S}_{9} \mathrm{C}\right]$ precursor and formation of the M-cluster. The delivery of Mo and homocitrate to NifEN is believed to be concerted, although the protein-protein interactions of the components that govern the transfer have not been studied in detail.

The maturation process also necessarily involves redox events, since the conversion of hexavalent molybdate to the more reduced form observed in the M-cluster (either tri- or tetravalent) must take place [15]. Mo K-edge XAS experiments of dithionite-reduced NifH in the presence of molybdate demonstrate that the Mo center becomes reduced and loses its oxo ligands upon binding within the protein, and addition of homocitrate to the solution leads to an even more activated metal center [4]. The nucleotide-dependent reduction of a vanadium(V) center has also been observed when orthovanadate was incubated with $\mathrm{NifH}$ [16], which suggests that the nucleotide may play a role in facilitating transition metal activation and reduction. Whether additional electrons are transferred to the Mo center during its transfer into NifEN, possibly through participation of the P-cluster-analogous $\left[\mathrm{Fe}_{4} \mathrm{~S}_{4}\right]$ cluster on the scaffold protein, is not well understood. Extending the analogy between the NifH:NifDK and NifH:NifEN complexes, nucleotide hydrolysis may be coupled with electron transfer as well, but the extent to which the Mo center is processed prior to complex formation has not yet been established.

\subsection{P-Cluster Formation}

The earliest assembly processes for NifDK, i.e., formation of the heterotetramer and insertion of simple $\left[\mathrm{Fe}_{4} \mathrm{~S}_{4}\right]$ clusters, are not well understood. In this regard, $\Delta$ nifH NifDK serves as a biosynthetic snapshot of a precursor form of the catalytic component. The isolated $\Delta$ nifH NifDK demonstrates 
that the complete "in situ" maturation of the P-cluster must precede the insertion of the M-cluster when generating the active form of the protein. No crystal structure of $\Delta$ nifH NifDK has been solved, but spectroscopic characterization of the variant reveals a protein with a conformation and cluster contents that differ from the wild type. More specifically, magnetic circular dichroism (MCD) [17], XAS [18], and EPR spectroscopy of $\triangle$ nifH NifDK indicate that the so-called $P^{*}$-cluster consists of a pair of " $\left[\mathrm{Fe}_{4} \mathrm{~S}_{4}\right]$-like" clusters at the $\alpha \beta$ interface. One subcluster appears to exhibit signals of a "ferrodoxin-like" cluster, while the other cluster has been formulated as an $\left[\mathrm{Fe}_{4} \mathrm{~S}_{4}\right]$ species in which one of the cluster sulfide $\left(\mathrm{S}^{2-}\right)$ corners of the cubane may be occupied by a cysteine thiolate ligand.

Incubation of $\mathrm{NifH}$ and $\triangle$ nifH NifDK under reducing conditions leads to the maturation of the two $\mathrm{P}^{*}$-clusters on the heterotetramer to P-clusters [19]. Monitoring of the Fe K-edge XAS during the maturation process revealed that P-cluster formation on each half of NifDK appears to proceed in a stepwise manner, with a lag in between. This observation is consistent with the properties observed in another Mo-nitrogenase mutant that has deletions in the genes nifB and nifZ. Deletion of nifB, a gene encoding for a protein that is essential for cofactor biosynthesis, leads to a catalytic component that lacks M-cluster, similar to $\triangle$ nifH NifDK. The removal of the gene nifZ, which encodes the small, chaperone-like protein NifZ, leads to expression of a catalytic component that contains P-cluster in one $\alpha \beta$ half and a $P^{*}$-cluster in the other half $[20,21]$. Interestingly, the single $P^{*}$-cluster on the so-called $\triangle$ nifB $\Delta$ nifZ NifDK variant cannot be matured to a P-cluster with addition of NifZ alone. Even though this variant is expressed in the presence of $\mathrm{NifH}$, the reductase component must still be added, along with NifZ, MgATP, and dithionite, to form the second P-cluster [21]. This result demonstrates that the actions of NifH for "in situ" P-cluster maturation on NifDK take place in an asymmetric, two-step process. For $\Delta$ nifB $\Delta$ nifZ NifDK, the first P-cluster is formed in vivo and likely involves nucleotide hydrolysis and electron transfer to effect reductive coupling of the $\mathrm{P}^{*}$-cluster. Fusion of the second $\mathrm{P}^{*}$-cluster to matured $\mathrm{P}$-cluster requires both $\mathrm{NifZ}$ and $\mathrm{NifH}$, which suggests that the environment at the second $\alpha \beta$ interface inherently differs from the first. How exactly NifH and NifZ cooperate in P-cluster maturation, and what role NifZ plays in the process, remain unanswered questions. The small, transition metal-free NifZ may assist in holding together the $\alpha$ and $\beta$ subunit halves of $\triangle$ nifB $\Delta$ nifZ NifDK to allow $\mathrm{NifH}$ to bind and fuse the $\mathrm{P}^{*}$-cluster, but more work is needed to evaluate this hypothesis and the surrounding details.

\subsection{Electron Transfer for Nitrogenase Catalysis}

After facilitating the "ex situ" and "in situ" maturation of the metallocofactors on NifDK, NifH plays its critical role as the obligate reductase component for the reduction of dinitrogen. Although other electron sources have been used to effect substrate reduction at NifDK [22-25], NifH is the only discrete electron source that can support homogeneous nitrogen fixation, indicating that formation of an interprotein complex is required to drive electrons to the active site and generate sufficiently reducing states. Electron transfer from NifH to NifDK first requires formation of a protein complex (see Section 3.2) and is nucleotide dependent (see Section 3.1), with two equivalents of MgATP cleaved per electron transferred [1].

The $\left[\mathrm{Fe}_{4} \mathrm{~S}_{4}\right]$ cluster of the Fe protein can exist with an overall $+2,+1$, or 0 charge. During catalytic turnover, the $\left[\mathrm{Fe}_{4} \mathrm{~S}_{4}\right]$ cluster cycles between the oxidized $2+$ and reduced +1 states. The +1 state is accessed in vitro with the reductant dithionite, whereas the in vivo reduction of NifH can be driven by physiological reductants such as flavodoxin and ferredoxin [26-30]. Mechanistic studies of electron transfer from NifH to NifDK suggest that upon complexation, the first electron transfer event occurs from the P-cluster to the active site M-cluster, after which the $\left[\mathrm{Fe}_{4} \mathrm{~S}_{4}\right]$ cluster of $\mathrm{NifH}$ reduces the now-oxidized P-cluster [31]. This proposed "deficit spending' model of electron transfer may represent a mechanism to prevent the backflow of electrons as increasing numbers of reducing equivalents are delivered to the catalytic component. The third $\left[\mathrm{Fe}_{4} \mathrm{~S}_{4}\right]^{0}$ oxidation state of the Fe protein is the so-called all-ferrous or "super-reduced" state [32]. Its relevance to the nitrogenase catalytic cycle has not been determined, and the properties of this species will be discussed in Section 3. 


\subsection{Adventitious Reactivity of Fe Proteins}

An additional function that has recently been identified for nitrogenase Fe proteins is not related to nitrogen fixation or cofactor biosynthesis [33]. Rebelein and co-workers discovered that both NifH and its counterpart from V-nitrogenase, $\mathrm{VnfH}$, could support the interconversion between carbon monoxide (CO) and carbon dioxide $\left(\mathrm{CO}_{2}\right)$ [34]. In the presence of an oxidizing dye with $\mathrm{CO}$ in the reaction headspace, isolated $\mathrm{NifH}$ or $\mathrm{VnfH}$ can catalyze the formation of $\mathrm{CO}_{2}$; conversely, in the presence of a reductant with $\mathrm{CO}_{2}$ in the headspace, the reverse reaction can be catalyzed. These results establish that nitrogenase Fe proteins by themselves can moonlight as carbon monoxide dehydrogenase $(\mathrm{CODH})$-like systems, although the amounts of product produced are lower by comparison.

Notably, the reduction of $\mathrm{CO}_{2}$ to $\mathrm{CO}$ has been observed both in vitro with the Fe proteins and in vivo with whole-cell $A$. vinelandii. The in vivo production of $\mathrm{CO}$ under a $\mathrm{CO}_{2}$ atmosphere has been definitively attributed to $\mathrm{NifH}$ (or $\mathrm{VnfH}$ ) by expression of the protein in a background containing deletions in the genes that encode for the catalytic component NifDK (or VnfDGK). In the presence of $\mathrm{NH}_{3}$, nitrogenase gene product expression is repressed [35], leading to no production of $\mathrm{CO}$, whereas omission of $\mathrm{NH}_{3}$ from the media leads to expression of the Fe protein and reduction of $\mathrm{CO}_{2}$ [34]. Thus, this adventitious substrate reduction function may occur under nitrogen-fixing conditions in vivo, but the prevalence of the reaction and its physiological implications are not known at this time.

\section{Features of the Fe Protein}

The crystal structure of NifH from A. vinelandii was first reported by Rees and co-workers in 1992 and was confirmed to be a homodimer with a total molecular weight of $\sim 60 \mathrm{kDa}$ [2]. A [Fe $\left.\mathrm{S}_{4}\right]$ cluster is located on a 2-fold rotation axis at the interface of the two subunits (Figure 2A) and is bound by two cysteine residues from each subunit (Cys97 and Cys132). The $\left[\mathrm{Fe}_{4} \mathrm{~S}_{4}\right]$ cluster is also positioned close to the surface of the protein (Figure 2B), a feature that is proposed to be relevant for nitrogenase reactivity and will be discussed below in more detail.
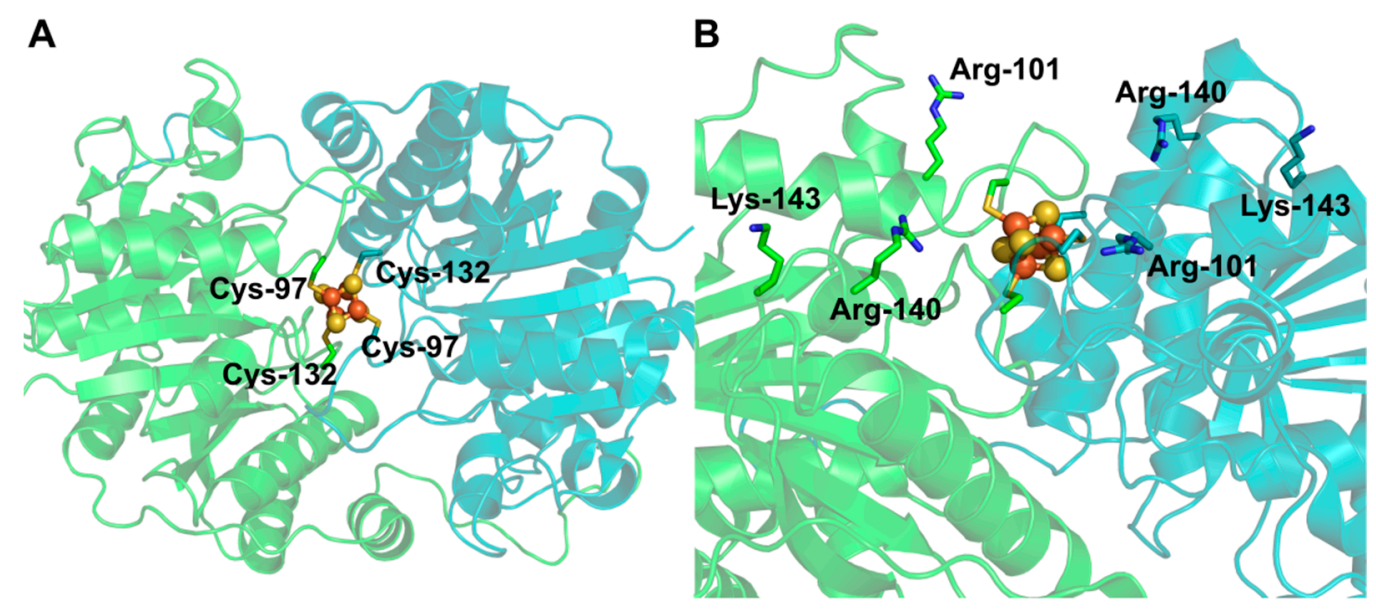

Figure 2. Crystal structure of $\mathrm{NifH}$ (PDB code 1G5P) [36] with subunit $\alpha$ shown in green and subunit $\beta$ shown in blue. A: representation of $\mathrm{NifH}$ as seen down the axis of symmetry. B: representation of $\mathrm{NifH}$ showing surface residues that have been identified as important for interactions with the MoFe protein. The Fe and $\mathrm{S}$ atoms of the $\left[\mathrm{Fe}_{4} \mathrm{~S}_{4}\right]$ cluster are shown as orange and yellow spheres, respectively.

As stated in Section 2.3, three different charge states for the $\left[\mathrm{Fe}_{4} \mathrm{~S}_{4}\right]$ cluster in the Fe protein have been identified. The +2 (oxidized) and +1 (reduced) states of the cluster are recognized as the operative states during catalysis. The oxidized $\left[\mathrm{Fe}_{4} \mathrm{~S}_{4}\right]^{2+}$ cluster is diamagnetic with an overall $S=0$ spin state and has parameters from Mössbauer spectroscopic analysis that are typical for a $\left[\mathrm{Fe}_{4} \mathrm{~S}_{4}\right]^{2+}$ cluster species [37]. The reduced $\left[\mathrm{Fe}_{4} \mathrm{~S}_{4}\right]^{+}$form of $\mathrm{NifH}$ is best described as a mixture of $S=1 / 2$ and 
$S=3 / 2$ species that can be easily interconverted through the use of different chemical additives [37]. This property is unique for an iron-sulfur containing protein, but the biological relevance of the spin state composition for reduced NifH has not been clearly established. The third charge state of $\mathrm{NifH}$ that was observed is a "super-reduced" $\left[\mathrm{Fe}_{4} \mathrm{~S}_{4}\right]^{0}$ cluster that has attracted considerable attention. Mössbauer spectroscopy indicates that reduction of the +1 state with a strong reductant (traditionally $\mathrm{Ti}(\mathrm{III})$ citrate or a $\mathrm{Eu}$ (II) chelate) generates an all-ferrous species, which is not known for any other [ $\left.\mathrm{Fe}_{4} \mathrm{~S}_{4}\right]$-containing system [38]. The species exhibits an unusual pink color [32], and parallel-mode EPR spectroscopy displays a signal consistent with either an $S=3$ or 4 spin state [38]. Detailed analysis of a synthetic all-ferrous $\left[\mathrm{Fe}_{4} \mathrm{~S}_{4}\right]$ cluster by Mössbauer, EPR and density functional theory (DFT) calculations, in comparison to the data obtained for the $\left[\mathrm{Fe}_{4} \mathrm{~S}_{4}\right]^{0} \mathrm{NifH}$ species, helped to establish that the ground state configuration for $\mathrm{NifH}$ is $S=4$ [39-41]. Moreover, the diagnostic color and signal has been observed in both super-reduced bacterial and archaeal Fe protein variants [42], indicating that access of this state is conserved among Fe proteins. Identification of a doubly reduced Fe protein suggests that perhaps the system could transfer two electrons per two ATP as a means to render a more efficient electron transfer during catalysis. As part of an investigation of physiological electron transfer to NifH, Watt and co-workers proposed another $\mathrm{NifH}\left[\mathrm{Fe}_{4} \mathrm{~S}_{4}\right]^{0}$ species, in complex with a physiologically relevant flavodoxin reductant, that had an $S=0$ spin state [43]. This assignment was based on ATP consumption stoichiometry, EPR and NMR analysis [43]; however, an $S=0$ state is spectroscopically "invisible" in EPR, and more sensitive magnetic measurements that could confirm the spin state, such as those from Mössbauer spectroscopy, were not reported. A crystal structure of NifH that is purportedly in the all-ferrous state has also been reported, but upon first glance it appears largely similar to other NifH structures [36]. The all-ferrous protein (PDB code 1G5P) has average Fe-S and Fe-Fe distances of $2.3 \AA$ and $2.7 \AA$, respectively, as well as an average Fe-S-Fe angle of $70.3^{\circ}$. Similarly, the oxidized protein $\left(\left[\mathrm{Fe}_{4} \mathrm{~S}_{4}\right]^{+}\right.$or $\left[\mathrm{Fe}_{4} \mathrm{~S}_{4}\right]^{2+}$, PDB code $\left.1 \mathrm{G} 1 \mathrm{M}\right)$ has average values for $\mathrm{Fe}-\mathrm{S}, \mathrm{Fe}-\mathrm{Fe}$, and $\mathrm{Fe}-\mathrm{S}-\mathrm{Fe}$ of $2.3 \AA, 2.6 \AA$ and $69.4^{\circ}$, respectively. It is unclear if the $\left[\mathrm{Fe}_{4} \mathrm{~S}_{4}\right]$ structures reflect the differences observed in the solution state because the protein species may have either been oxidized during the crystallization process or photoreduced by the X-ray beam during data collection, so the oxidation state of the metal atoms in the crystals is ambiguous [36]. Münck and co-workers were able to shed light on the structure of the $S=4$ all-ferrous iron-sulfur cluster of NifH by comparison to a synthetic analog, as mentioned above [40,41]. One of the four Fe centers in the cluster was determined to be in a unique environment, consistent with a $C_{3 \mathrm{v}}$ cluster symmetry, and this unique configuration is not observed in more oxidized $\left[\mathrm{Fe}_{4} \mathrm{~S}_{4}\right]$ clusters [40], adding to the intrigue of this species. While much effort has gone into the study of the all-ferrous Fe protein, further characterization will be required to understand the physiological and catalytic relevance of this state.

$\mathrm{NifH}$ is currently the only Fe protein of a nitrogenase that has a structure derived from X-ray crystallography (see Table 1). Despite this, there are several factors that suggest that the Fe proteins of the alternative nitrogenases, $\mathrm{VnfH}$ and $\mathrm{AnfH}$, have similar structures to that of $\mathrm{NifH}$. In A. vinelandii, the Fe proteins have relatively high sequence identity, with $\mathrm{VnfH}$ at $\sim 90 \%$ and $\mathrm{AnfH}$ at $\sim 60 \%$ compared to $\mathrm{NifH}$ [8], and $\mathrm{VnfH}$ and AnfH have conserved cysteine residues indicative of [FeS] cluster binding. The dithionite-reduced Fe proteins all display a characteristic EPR spectrum composed of a mixture of $S=1 / 2$ and $S=3 / 2$ resonances $[44,45]$, indicating that a similar type of $\left[\mathrm{Fe}_{4} \mathrm{~S}_{4}\right]$ cluster is present in each system. In support of this notion, analysis of the $\mathrm{NifH}, \mathrm{VnfH}$, and AnfH by XAS has demonstrated that the [FeS] clusters in each protein have a very similar structure. The characterization of $\mathrm{VnfH}$ and AnfH is rather limited compared to $\mathrm{NifH}$, but one of the main differences between these systems is related to the reactivity. As mentioned above, both $\mathrm{NifH}$ and $\mathrm{VnfH}$ specifically incorporate their respective metal (Mo for $\mathrm{NifH}, \mathrm{V}$ for $\mathrm{VnfH}$ ) into the nitrogenase cluster, but the structural origin of this difference in specificity is still unknown and warrants further investigation. It is also unclear if AnfH plays an analogous maturase role in the Fe-only nitrogenase system, since no anfEN gene has been identified, and the precise composition of the catalytic cofactor in the FeFe protein has not been determined. 
Table 1. Select crystal structures of the Fe protein component of nitrogenase.

\begin{tabular}{|c|c|c|c|}
\hline Protein & PDB Code & Resolution $(\AA)$ & Reference \\
\hline $\mathrm{NifH}$ & 1G5P & 2.2 & [36] \\
\hline $\mathrm{NifH}$ as $\left[\mathrm{Fe}_{4} \mathrm{~S}_{4}\right]^{0}$ "all ferrous" & $1 \mathrm{G} 1 \mathrm{M}$ & 2.25 & [36] \\
\hline $\mathrm{NifH}+\mathrm{MgADP}$ & $1 \mathrm{FP} 6$ & 2.15 & [46] \\
\hline$\Delta \mathrm{L} 127-\mathrm{NifH}+\mathrm{MgATP}$ & $2 \mathrm{C} 8 \mathrm{~V}$ & 2.5 & [47] \\
\hline $\mathrm{NifH}+\mathrm{NifDK}$ & $2 \mathrm{AFH}$ & 2.1 & [48] \\
\hline$\Delta \mathrm{L} 127-\mathrm{NifH}+\mathrm{NifDK}+\mathrm{MgATP}$ & $1 G 21$ & 3.0 & [3] \\
\hline NifH + NifDK + MgAMPPCP & 4WZB & 2.3 & [48] \\
\hline $\mathrm{NifH}+\mathrm{NifDK}+\mathrm{MgAMP} \cdot \mathrm{AlF}_{4}{ }^{-}$ & $1 \mathrm{~N} 2 \mathrm{C}$ & 3.0 & [49] \\
\hline $\mathrm{NifH}+\mathrm{NifDK}+\mathrm{MgADP}$ & 2AFI & 3.1 & [48] \\
\hline NifH + NifDK + MgADP/MgAMPPCP & 4WZA & 1.9 & [48] \\
\hline
\end{tabular}

\subsection{Nucleotide Binding to NifH}

As seen in Equation (1), MgATP and its hydrolysis is required for nitrogenase catalysis and is an important driving force for P-cluster and M-cluster assembly as well (see Section 2) $[4,10,12]$. For many years, NifH was suggested to be an ATP-binding protein based on sequence similarity to other nucleotide-binding proteins [50] and site-directed mutagenesis [1]. When the crystal structure of the Fe protein from A. vinelandii was solved in 1992 [2], a Walker's motif A [51] was identified between residues 9 and 16 that was indicative of a nucleotide binding site [52]. The partial occupancy of an ADP molecule in the 1992 crystal structure gave preliminary indications of how the nucleotide could bind to NifH, but a series of subsequent structures were solved with better-resolved MgADP [46] and MgATP [47] molecules.

For non-complexed, wild-type $\mathrm{NifH}$, the structures with and without $\mathrm{MgADP}$ are very similar to each other (Figure 3), indicating that there are only minor conformational changes to the protein fold upon nucleotide binding. Additionally, a single residue deletion variant ( $\triangle \mathrm{L} 127-\mathrm{NifH})$ that is incapable of nucleotide hydrolysis was also crystallized with MgATP bound, and this structure is similarly unchanged compared to the MgADP-bound and nucleotide free structures [47]. However, as solid-state snapshots, these structures are not necessarily representative of the conformational dynamics operative in solution.

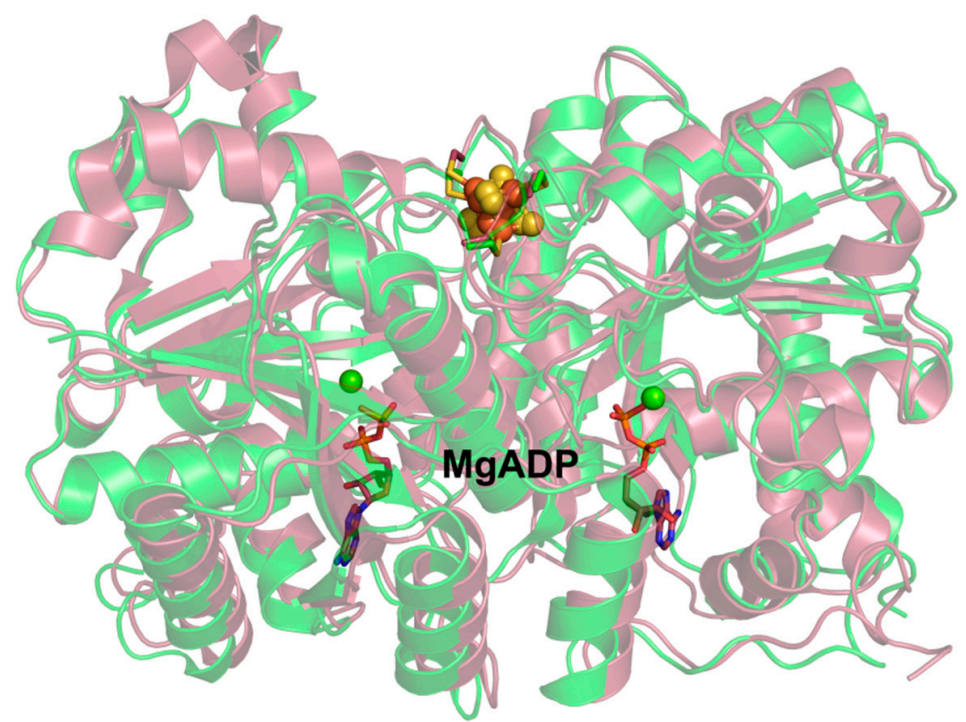

Figure 3. Overlaid crystal structures of NifH (green cartoon, PDB code 1G5P) and NifH bound with MgADP (purple cartoon, PDB code 1FP6). The $\left[\mathrm{Fe}_{4} \mathrm{~S}_{4}\right]$ clusters of both proteins are in a similar position, shown in a ball and stick model. The ADP molecules are shown in a stick model. The $\mathrm{Mg}$, Fe and $\mathrm{S}$ atoms are represented by green, orange, and yellow spheres, respectively. 
Before crystal structures were available, attempts to gain structural insight into binding of MgATP in the Fe protein focused on spectroscopic and biochemical characterization. Binding of nucleotide to $\mathrm{NifH}$ changes the EPR spectroscopic signal lineshapes [1], suggesting a connection between the electron transfer from the $\left[\mathrm{Fe}_{4} \mathrm{~S}_{4}\right]$ cluster and nucleotide coordination despite the $\sim 20 \AA$ distance between the metallocluster and nucleotide binding sites. Corroborating this assessment is the measurement of the midpoint reduction potentials in NifH with and without nucleotide. When MgADP or MgATP bind within $\mathrm{NifH}$, the reduction potential decreases by $\sim 100 \mathrm{mV}$ compared to that of the nucleotide-free species, demonstrating an intimate relationship between these features [53]. Colorimetric chelation assays also reveal a modulation of the protein properties in the presence of nucleotide. In the absence of MgATP, chelating agents such as 2,2'-bipyridine and bathophenanthrolinedisulfonate are unable to [54] or have limited capability to [55] remove the Fe from the $\left[\mathrm{Fe}_{4} \mathrm{~S}_{4}\right]$ cluster of NifH. In contrast, when ATP is bound to NifH, Fe is rapidly removed from the metallocluster in the presence of these same chelating agents [54-56]. These results indicate that limited chelator access to the $\left[\mathrm{Fe}_{4} \mathrm{~S}_{4}\right]$ cluster takes place in the absence of MgATP, but with nucleotide-bound $\mathrm{NifH}$, the cluster is rendered more solvent exposed. In addition, the oxidation state of the cluster also affects the extent of Fe chelation relative to that of the dithionite-reduced form of $\mathrm{NifH}$ [57]. As stated above, a change in the protein is also supported by the different EPR spectra of NifH observed in the presence and absence of MgATP, consistent with an apparent connection between the cluster properties and nucleotide binding [58-60]. The nucleotide binding behavior becomes more complicated when the MgATP hydrolysis product and nitrogenase inhibitor MgADP is taken into account. A litany of experimental evidence suggests that MgADP binds more tightly to NifH than does MgATP [61] and has a more mild effect on the NifH structure [1]. Analogous Fe chelation studies demonstrate that the $\left[\mathrm{Fe}_{4} \mathrm{~S}_{4}\right]$ cluster of MgADP-bound $\mathrm{NifH}$ remains stable in the presence of the chelating agents [57,62], in contrast to the experiments with MgATP. This effect was also studied by small angle X-ray scattering (SAXS), which provides a structural indicator of the protein conformation in a frozen solution and does not require crystalline material. The results of these studies demonstrated that MgATP binding to NifH caused a measurable change in the protein conformation as compared to that of either MgADP-bound or nucleotide-free $\mathrm{NifH}$, which were indistinguishable from each other [63]. All of these experiments collectively support the idea that there are different conformations of the Fe protein depending on nucleotide binding that specifically change the spectroscopic parameters and the accessibility of the $\left[\mathrm{Fe}_{4} \mathrm{~S}_{4}\right]$ cluster to the solvent. Unfortunately, the available crystal structures of NifH do not reflect the dynamic nature of the protein in solution, and therefore, caution should be taken when interpreting the structure with respect to protein function. However, nucleotide-induced conformational changes are observed by X-ray methods when NifH is complexed with NifDK, consistent with the chelation experiments (see Section 3.2).

\subsection{The NifH and NifDK Protein Complex}

Prior to the solving of the first NifH:NifDK complex crystal structure, docking models based on the individual protein structures had predicted the amino acid patches that likely participated in the interprotein interactions. One strategy utilized was the chemical cross-linking of NifH and NifDK to form a functional nitrogenase species $[64,65]$. Analysis of the resulting protein species identified that the surface residue Glu112 on NifH was involved in the crosslink, indicating a potential site of docking. Subsequent site-directed mutagenesis studies were focused on individually selecting surface resides and measuring the effect on nitrogenase catalysis. Several residues, Arg100, Arg140, and Lys143 (Figure 2B), were all found to affect catalysis when the residues were mutated and generally resulted in inefficient or completely uncoupled electron transfer to NifDK [66-69]. Indeed, these predictions and docking studies were validated and refined in 1997 when a crystal structure of the complex formed between the two components of Mo-nitrogenase was first reported by Rees and co-workers [49]. Since the interaction of the two components under reducing conditions in the presence of MgATP leads to spontaneous nucleotide hydrolysis and substrate reduction (i.e., $\mathrm{H}_{2}$ formation), the complex 
was locked in its conformation by instead using $\mathrm{MgADP} \cdot \mathrm{AlF}_{4}$, a non-hydrolyzable MgATP analog (Figure $4 \mathrm{~A}$ ). The MgADP. $\mathrm{AlF}_{4}$-loaded $\mathrm{NifH}$ in this complex is proposed to represent a transition state analog of the MgATP-bound species, with the $\mathrm{AlF}_{4}{ }^{-}$unit located at the $\gamma$-phosphate position. Notably, the conformation of complexed $\mathrm{NifH}$ varies greatly from structures of $\mathrm{NifH}$ alone, indicating that complexation with NifDK provides a reliable strategy to visualize the reductase component in a catalytically relevant state.

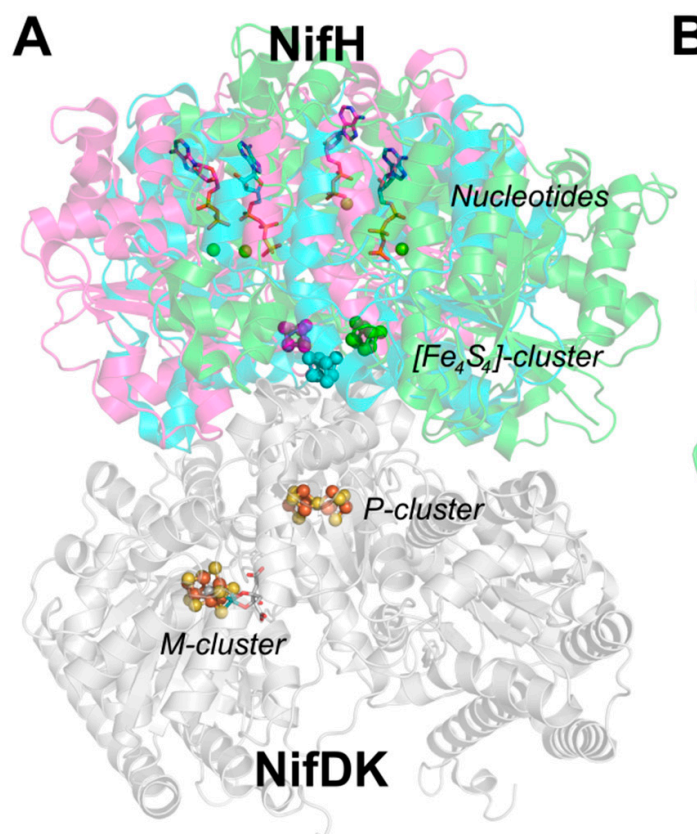

\section{B}

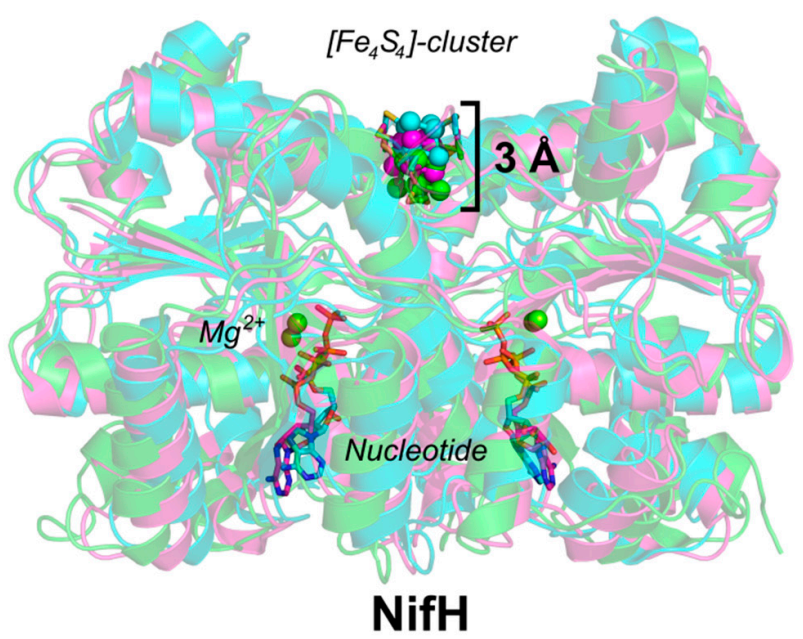

Figure 4. Overlaid crystal structure of NifH:NifDK complex with various nucleotides bound. A: The NifDK protein (gray cartoon, PDB code 2AFH) in complex with NifH (green cartoon, PDB code 2AFH), MgADP-bound NifH (purple cartoon, PDB code 2AFI) and MgATP-bound $\triangle$ L127-NifH (cyan cartoon, PDB code 1G21). B: The aligned crystal structures of the NifH proteins from the NifH:NifDK complexes represented in panel A. The $\left[\mathrm{Fe}_{4} \mathrm{~S}_{4}\right]$ clusters of $\mathrm{NifH}$ are shown as spheres of the same color as the cartoon. The nucleotides are represented in a stick model; $\mathrm{Mg}$ atoms are shown as light green spheres.

Since that initial publication, several other methods have been used to generate and study NifH:NifDK complexes. Rees and co-workers have been successful in these efforts and have been able to acquire a crystal structure of the NifH:NifDK complex without nucleotide bound as well as the MgADP- and MgAMPPCP-bound (a non-hydrolyzable ATP analog) NifH:NifDK structures (Figure 4) [48]. In addition, the hydrolysis-defective $\Delta$ L127-NifH variant with MgATP bound has also been crystallized in complex with NifDK [3]. Interestingly, for all of the crystal structures mentioned above, the NifH protein fragment has a different orientation while binding to NifDK. In the nucleotide-free, MgADP, and MgATP-bound states of $\mathrm{NifH}$, the $\left[\mathrm{Fe}_{4} \mathrm{~S}_{4}\right]$ cluster is $\sim 22 \AA, 21 \AA$, and $17 \AA$ away from the P-cluster of NifDK, respectively. Viewing the overlaid complex structures (Figure 4A) illustrates a putative "rolling" movement of NifH across the surface of NifDK during electron transfer and nucleotide hydrolysis.

A comparison of just the Fe protein portions of the NifH:NifDK structures provides additional insight into the structural dynamics at play in the solution state. When the NifH fragments are aligned, the overall protein structures are similar, but notably, there is a $3 \AA$ displacement of the $\left[\mathrm{Fe}_{4} \mathrm{~S}_{4}\right]$ cluster between the nucleotide-free and MgATP-bound states of $\mathrm{NifH}$ (Figure 4B). The $\left[\mathrm{Fe}_{4} \mathrm{~S}_{4}\right]$ cluster of the MgATP-bound NifH state is thus more extended from the protein to place it in closer proximity to the NifDK P-cluster. This displacement is consistent with the solution-state Fe chelation 
studies (see Section 3.1) in which the $\left[\mathrm{Fe}_{4} \mathrm{~S}_{4}\right]$ cluster of nucleotide-bound $\mathrm{NifH}$ was more susceptible to chelation (i.e., less buried and more accessible to the solvent) than in the nucleotide-free state. Since NifH loaded with MgATP allows the $\left[\mathrm{Fe}_{4} \mathrm{~S}_{4}\right]$ cluster to more closely approach the P-cluster than in the nucleotide-free or MgADP-bound states, this state likely represents the point of optimal electron transfer to the P-cluster. Electron transfer at this stage is proposed to trigger ATP hydrolysis that should lead to a conformation similar to the complexed, MgADP-bound NifH structure. The conformational rearrangements moving the $\left[\mathrm{Fe}_{4} \mathrm{~S}_{4}\right]$ cluster also likely prevent "backflow" of the transferred electron from the P-cluster to NifH. Kinetics studies of NifH in complex with NifDK support the idea that after electron transfer to NifDK, nucleotide hydrolysis occurs; however, how exactly oxidation of the $\left[\mathrm{Fe}_{4} \mathrm{~S}_{4}\right]$ cluster is tied to conformational changes and nucleotide hydrolysis has not been determined. Regardless, the rate-limiting step of the NifH:NifDK interaction has been shown to be the release of $P_{i}$ from the protein after ATP hydrolysis, rather than protein association or dissociation [70].

To date, only one crystal structure has been reported of a NifH:NifDK complex in which the nucleotides within $\mathrm{NifH}$ are asymmetrically bound; in this case, the protein was bound with one MgAMPPCP and one MgADP molecule [71]. This structure hints at the possibility of sequential cleavage of MgATP molecules as opposed to a concerted mechanism wherein both nucleotides are hydrolyzed together, and this has implications for the regulation of nitrogenase reactivity. Seefeldt and co-workers have observed cooperative binding of nucleotide in $\mathrm{NifH}$, where the binding affinity for the second nucleotide molecule is higher than for the first [72]. Along these lines, Rees and co-workers proposed that the sequential MgATP cleavage and release of $\mathrm{P}_{\mathrm{i}}$ from $\mathrm{NifH}$ provides a type of timing mechanism for controlling electron transfer in the catalytic complex [71]. From the MgATP-bound complex, an electron can be transferred coupled with MgADP formation, and this could induce a structural change that facilitates the release of NifH from NifDK and prevents uncoupled electron backflow.

\section{Conclusions}

The nitrogenase Fe protein is often outshined by the impressive substrate-reducing feats of the catalytic component, but this protein plays crucial roles behind the scenes. Beyond its role as the canonical redox partner of NifDK, NifH catalyzes the "in situ" maturation of P-cluster on NifDK and the "ex situ" maturation of M-cluster on NifEN. Nucleotide hydrolysis and electron transfer are believed to be intimately tied to these three important processes, although the exact nature of the structure-function relationships in relation to conformational changes and interprotein interactions remains a mystery. Furthermore, nitrogenase Fe proteins alone can facilitate reduction of the substrate $\mathrm{CO}_{2}$ to $\mathrm{CO}$. The respective Fe proteins of $\mathrm{V}$ - and Fe-nitrogenases, $\mathrm{VnfH}$ and $\mathrm{AnfH}$, are similar to their Mo-nitrogenase counterpart, but much more work is needed to evaluate if these proteins fully perform the analogous tasks or may even harbor additional, as-yet-undiscovered reactivity.

Acknowledgments: This work was supported by NIH-NIGMS grant GM67626 (to Markus W. Ribbe and Yilin Hu) and NSF Career grant CHE-1651398 (to Yilin Hu).

Author Contributions: Andrew J. Jasniewski, Nathaniel S. Sickerman, Yilin Hu, and Markus W. Ribbe wrote the paper.

Conflicts of Interest: The authors declare no conflict of interest.

\section{References}

1. Burgess, B.K.; Lowe, D.J. Mechanism of molybdenum nitrogenase. Chem. Rev. 1996, 96, 2983-3012. [CrossRef] [PubMed]

2. Georgiadis, M.; Komiya, H.; Chakrabarti, P.; Woo, D.; Kornuc, J.; Rees, D. Crystallographic structure of the nitrogenase iron protein from Azotobacter vinelandii. Science 1992, 257, 1653-1659. [CrossRef] [PubMed] 
3. Chiu, H.-J.; Peters, J.W.; Lanzilotta, W.N.; Ryle, M.J.; Seefeldt, L.C.; Howard, J.B.; Rees, D.C. MgAPT-bound and nucleotide-free structures of a nitrogenase protein complex between the Leu $127 \delta$-Fe-protein and the MoFe-protein. Biochemistry 2001, 40, 641-650. [CrossRef] [PubMed]

4. Hu, Y.; Corbett, M.C.; Fay, A.W.; Webber, J.A.; Hodgson, K.O.; Hedman, B.; Ribbe, M.W. Nitrogenase Fe protein: A molybdate/homocitrate insertase. Proc. Natl. Acad. Sci. USA 2006, 103, 17125-17130. [CrossRef] [PubMed]

5. Ribbe, M.W.; Hu, Y.; Guo, M.; Schmid, B.; Burgess, B.K. The femoco-deficient MoFe protein produced by a nifH deletion strain of Azotobacter vinelandii shows unusual P-cluster features. J. Biol. Chem. 2002, 277, 23469-23476. [CrossRef] [PubMed]

6. Lee, C.C.; Blank, M.A.; Fay, A.W.; Yoshizawa, J.M.; Hu, Y.; Hodgson, K.O.; Hedman, B.; Ribbe, M.W. Stepwise formation of P-cluster in nitrogenase MoFe protein. Proc. Natl. Acad. Sci. USA 2009, 106, 18474-18478. [CrossRef] [PubMed]

7. Rubio, L.M.; Ludden, P.W. Biosynthesis of the iron-molybdenum cofactor of nitrogenase. Annu. Rev. Microbiol. 2008, 62, 93-111. [CrossRef] [PubMed]

8. Eady, R.R. Structure-function relationships of alternative nitrogenases. Chem. Rev. 1996, 96, 3013-3030. [CrossRef] [PubMed]

9. Ribbe, M.W.; Hu, Y.; Hodgson, K.O.; Hedman, B. Biosynthesis of nitrogenase metalloclusters. Chem. Rev. 2014, 114, 4063-4080. [CrossRef] [PubMed]

10. Hu, Y.; Fay, A.W.; Ribbe, M.W. Identification of a nitrogenase FeMo cofactor precursor on NifEN complex. Proc. Natl. Acad. Sci. USA 2005, 102, 3236-3241. [CrossRef] [PubMed]

11. Kaiser, J.T.; Hu, Y.; Wiig, J.A.; Rees, D.C.; Ribbe, M.W. Structure of precursor-bound NifEN: A nitrogenase femo cofactor maturase/insertase. Science 2011, 331, 91-94. [CrossRef] [PubMed]

12. Hu, Y.; Corbett, M.C.; Fay, A.W.; Webber, J.A.; Hodgson, K.O.; Hedman, B.; Ribbe, M.W. FeMo cofactor maturation on NifEN. Proc. Natl. Acad. Sci. USA 2006, 103, 17119-17124. [CrossRef] [PubMed]

13. Fay, A.W.; Wiig, J.A.; Lee, C.C.; Hu, Y. Identification and characterization of functional homologs of nitrogenase cofactor biosynthesis protein NifB from methanogens. Proc. Natl. Acad. Sci. USA 2015, 112, 14829-14833. [CrossRef] [PubMed]

14. Hernandez, J.A.; Curatti, L.; Aznar, C.P.; Perova, Z.; Britt, R.D.; Rubio, L.M. Metal trafficking for nitrogen fixation: NifQ donates molybdenum to NifEN/NifH for the biosynthesis of the nitrogenase FeMo-cofactor. Proc. Natl. Acad. Sci. USA 2008, 105, 11679-11684. [CrossRef] [PubMed]

15. Bjornsson, R.; Lima, F.A.; Spatzal, T.; Weyhermuller, T.; Glatzel, P.; Bill, E.; Einsle, O.; Neese, F.; DeBeer, S. Identification of a spin-coupled $\mathrm{Mo}(\mathrm{III})$ in the nitrogenase iron-molybdenum cofactor. Chem. Sci. 2014, 5, 3096-3103. [CrossRef]

16. Fisher, K.; Lowe, D.J.; Petersen, J. Vanadium(v) is reduced by the 'as isolated' nitrogenase Fe-protein at neutral pH. Chem. Commun. 2006, 2807-2809. [CrossRef]

17. Broach, R.B.; Rupnik, K.; Hu, Y.; Fay, A.W.; Cotton, M.; Ribbe, M.W.; Hales, B.J. Variable-temperature, variable-field magnetic circular dichroism spectroscopic study of the metal clusters in the $\Delta n i f B$ and $\Delta$ nifH MoFe proteins of nitrogenase from Azotobacter vinelandii. Biochemistry 2006, 45, 15039-15048. [CrossRef] [PubMed]

18. Corbett, M.C.; Hu, Y.; Naderi, F.; Ribbe, M.W.; Hedman, B.; Hodgson, K.O. Comparison of iron-molybdenum cofactor-deficient nitrogenase MoFe proteins by X-ray absorption spectroscopy: Implications for P-cluster biosynthesis. J. Biol. Chem. 2004, 279, 28276-28282. [CrossRef] [PubMed]

19. Hu, Y.; Corbett, M.C.; Fay, A.W.; Webber, J.A.; Hedman, B.; Hodgson, K.O.; Ribbe, M.W. Nitrogenase reactivity with P-cluster variants. Proc. Natl. Acad. Sci. USA 2005, 102, 13825-13830. [CrossRef] [PubMed]

20. Hu, Y.; Fay, A.W.; Dos Santos, P.C.; Naderi, F.; Ribbe, M.W. Characterization of Azotobacter vinelandii nifZ deletion strains: Indication of stepwise MoFe protein assembly. J. Biol. Chem. 2004, 279, 54963-54971. [CrossRef] [PubMed]

21. Cotton, M.S.; Rupnik, K.; Broach, R.B.; Hu, Y.; Fay, A.W.; Ribbe, M.W.; Hales, B.J. VTVH-MCD study of the $\Delta$ nifB $\Delta$ nifZ MoFe protein from Azotobacter vinelandii. J. Am. Chem. Soc. 2009, 131, 4558-4559. [CrossRef] [PubMed]

22. Brown, K.A.; Harris, D.F.; Wilker, M.B.; Rasmussen, A.; Khadka, N.; Hamby, H.; Keable, S.; Dukovic, G.; Peters, J.W.; Seefeldt, L.C.; et al. Light-driven dinitrogen reduction catalyzed by a CdS:Nitrogenase MoFe protein biohybrid. Science 2016, 352, 448-450. [CrossRef] [PubMed] 
23. Tanifuji, K.; Lee, C.C.; Ohki, Y.; Tatsumi, K.; Hu, Y.; Ribbe, M.W. Combining a nitrogenase scaffold and a synthetic compound into an artificial enzyme. Angew. Chem. Int. Ed. 2015, 54, 14022-14025. [CrossRef] [PubMed]

24. Milton, R.D.; Abdellaoui, S.; Khadka, N.; Dean, D.R.; Leech, D.; Seefeldt, L.C.; Minteer, S.D. Nitrogenase bioelectrocatalysis: Heterogeneous ammonia and hydrogen production by MoFe protein. Energy Environ. Sci. 2016, 9, 2550-2554. [CrossRef]

25. Rebelein, J.G.; Hu, Y.; Ribbe, M.W. Widening the product profile of carbon dioxide reduction by vanadium nitrogenase. ChemBioChem 2015, 16, 1993-1996. [CrossRef] [PubMed]

26. Yates, M.G. Electron transport to nitrogenase in Azotobacter chroococcum: Azotobacter flavodoxin hydroquinone as an electron donor. FEBS Lett. 1972, 27, 63-67. [CrossRef]

27. Duyvis, M.G.; Wassink, H.; Haaker, H. Nitrogenase of Azotobacter vinelandii: Kinetic analysis of the Fe protein redox cycle. Biochemistry 1998, 37, 17345-17354. [CrossRef] [PubMed]

28. Bennett, L.T.; Jacobson, M.R.; Dean, D.R. Isolation, sequencing, and mutagenesis of the nifF gene encoding flavodoxin from Azotobacter vinelandii. J. Biol. Chem. 1988, 263, 1364-1369. [PubMed]

29. Thorneley, R.N.; Deistung, J. Electron-transfer studies involving flavodoxin and a natural redox partner, the iron protein of nitrogenase. Conformational constraints on protein-protein interactions and the kinetics of electron transfer within the protein complex. Biochem. J. 1988, 253, 587-595. [CrossRef] [PubMed]

30. Martin, A.E.; Burgess, B.K.; Iismaa, S.E.; Smartt, C.T.; Jacobson, M.R.; Dean, D.R. Construction and characterization of an Azotobacter vinelandii strain with mutations in the genes encoding flavodoxin and ferredoxin I. J. Bacteriol. 1989, 171, 3162-3167. [CrossRef] [PubMed]

31. Danyal, K.; Dean, D.R.; Hoffman, B.M.; Seefeldt, L.C. Electron transfer within nitrogenase: Evidence for a deficit-spending mechanism. Biochemistry 2011, 50, 9255-9263. [CrossRef] [PubMed]

32. Watt, G.D.; Reddy, K.R.N. Formation of an all ferrous $\mathrm{Fe}_{4} \mathrm{~S}_{4}$ cluster in the iron protein component of Azotobacter vinelandii nitrogenase. J. Inorg. Biochem. 1994, 53, 281-294. [CrossRef]

33. Sickerman, N.S.; Hu, Y.; Ribbe, M.W. Activation of $\mathrm{CO}_{2}$ by vanadium nitrogenase. Chem. Asian J. 2017, 12, 1985-1996. [CrossRef] [PubMed]

34. Rebelein, J.G.; Stiebritz, M.T.; Lee, C.C.; Hu, Y. Activation and reduction of carbon dioxide by nitrogenase iron proteins. Nat. Chem. Biol. 2016, 13, 147-149. [CrossRef] [PubMed]

35. Kennedy, C.; Bali, A.; Blanco, G.; Contreras, A.; Drummond, M.; Merrick, M.; Walmsley, J.; Woodley, P. Regulation of expression of genes for three nitrogenases in Azotobacter vinelandii. In Nitrogen Fixation: Proceedings of the Fifth International Symposium on Nitrogen Fixation with Non-Legumes, Florence, Italy, 10-14 September 1990; Polsinelli, M., Materassi, R., Vincenzini, M., Eds.; Springer: Dordrecht, The Netherlands, 1991; pp. 13-23.

36. Strop, P.; Takahara, P.M.; Chiu, H.-J.; Angove, H.C.; Burgess, B.K.; Rees, D.C. Crystal structure of the all-ferrous $[4 \mathrm{Fe}-4 \mathrm{~S}]^{0}$ form of the nitrogenase iron protein from Azotobacter vinelandii. Biochemistry 2001, 40, 651-656. [CrossRef] [PubMed]

37. Lindahl, P.A.; Day, E.P.; Kent, T.A.; Orme-Johnson, W.H.; Münck, E. Mössbauer, epr, and magnetization studies of the Azotobacter vinelandii Fe protein. Evidence for a $[4 \mathrm{Fe}-4 \mathrm{~S}]^{1+}$ cluster with spin $\mathrm{S}=3 / 2$. J. Biol. Chem. 1985, 260, 11160-11173. [PubMed]

38. Angove, H.C.; Yoo, S.J.; Burgess, B.K.; Münck, E. Mössbauer and EPR evidence for an all-ferrous $\mathrm{Fe}_{4} \mathrm{~S}_{4}$ cluster with $S=4$ in the Fe protein of nitrogenase. J. Am. Chem. Soc. 1997, 119, 8730-8731. [CrossRef]

39. Yoo, S.J.; Angove, H.C.; Burgess, B.K.; Hendrich, M.P.; Münck, E. Mössbauer and integer-spin EPR studies and spin-coupling analysis of the $[4 \mathrm{Fe}-4 \mathrm{~S}]^{0}$ cluster of the Fe protein from Azotobacter vinelandii nitrogenase. J. Am. Chem. Soc. 1999, 121, 2534-2545. [CrossRef]

40. Chakrabarti, M.; Deng, L.; Holm, R.H.; Münck, E.; Bominaar, E.L. Mössbauer, electron paramagnetic resonance, and theoretical studies of a carbene-based all-ferrous $\mathrm{Fe}_{4} \mathrm{~S}_{4}$ cluster: Electronic origin and structural identification of the unique spectroscopic site. Inorg. Chem. 2009, 48, 2735-2747. [CrossRef] [PubMed]

41. Chakrabarti, M.; Münck, E.; Bominaar, E.L. Density functional theory study of an all ferrous 4 Fe- 4 S cluster. Inorg. Chem. 2011, 50, 4322-4326. [CrossRef] [PubMed]

42. Hiller, C.J.; Stiebritz, M.T.; Lee, C.C.; Liedtke, J.; Hu, Y. Tuning electron flux through nitrogenase with methanogen iron protein homologues. Chem. Eur. J. 2017, 23, 16152-16156. [CrossRef] [PubMed] 
43. Lowery, T.J.; Wilson, P.E.; Zhang, B.; Bunker, J.; Harrison, R.G.; Nyborg, A.C.; Thiriot, D.; Watt, G.D. Flavodoxin hydroquinone reduces Azotobacter vinelandii Fe protein to the all-ferrous redox state with a $S=0$ spin state. Proc. Natl. Acad. Sci. USA 2006, 103, 17131-17136. [CrossRef] [PubMed]

44. Onate, Y.A.; Finnegan, M.G.; Hales, B.J.; Johnson, M.K. Variable temperature magnetic circular dichroism studies of reduced nitrogenase iron proteins and $[4 \mathrm{Fe}-4 \mathrm{~S}]^{+}$synthetic analog clusters. Biochim. Biophys. Acta Protein Struct. Mol. 1993, 1164, 113-123. [CrossRef]

45. Blank, M.A.; Lee, C.C.; Hu, Y.; Hodgson, K.O.; Hedman, B.; Ribbe, M.W. Structural models of the [Fe $\left.\mathrm{F}_{4}\right]$ clusters of homologous nitrogenase fe proteins. Inorg. Chem. 2011, 50, 7123-7128. [CrossRef] [PubMed]

46. Jang, S.B.; Seefeldt, L.C.; Peters, J.W. Insights into nucleotide signal transduction in nitrogenase: Structure of an iron protein with MgADP bound. Biochemistry 2000, 39, 14745-14752. [CrossRef] [PubMed]

47. Sen, S.; Krishnakumar, A.; McClead, J.; Johnson, M.K.; Seefeldt, L.C.; Szilagyi, R.K.; Peters, J.W. Insights into the role of nucleotide-dependent conformational change in nitrogenase catalysis: Structural characterization of the nitrogenase Fe protein Leu127 deletion variant with bound MgATP. J. Inorg. Biochem. 2006, 100, 1041-1052. [CrossRef] [PubMed]

48. Tezcan, F.A.; Kaiser, J.T.; Mustafi, D.; Walton, M.Y.; Howard, J.B.; Rees, D.C. Nitrogenase complexes: Multiple docking sites for a nucleotide switch protein. Science 2005, 309, 1377-1380. [CrossRef] [PubMed]

49. Schindelin, H.; Kisker, C.; Schlessman, J.L.; Howard, J.B.; Rees, D.C. Structure of ADP.AlF 4 -Stabilized nitrogenase complex and its implications for signal transduction. Nature 1997, 387, 370-376. [CrossRef] [PubMed]

50. Robson, R.L. Identification of possible adenine nucleotide-binding sites in nitrogenase Fe- and MoFe-proteins by amino acid sequence comparison. FEBS Lett. 1984, 173, 394-398. [CrossRef]

51. Walker, J.E.; Saraste, M.; Runswick, M.J.; Gay, N.J. Distantly related sequences in the alpha- and beta-subunits of ATP synthase, myosin, kinases and other ATP-requiring enzymes and a common nucleotide binding fold. EMBO J. 1982, 1, 945-951. [PubMed]

52. Schulz, G.E. Binding of nucleotides by proteins. Curr. Opin. Struct. Biol. 1992, 2, 61-67. [CrossRef]

53. Lanzilotta, W.N.; Ryle, M.J.; Seefeldt, L.C. Nucleotide hydrolysis and protein conformational changes in Azotobacter vinelandii nitrogenase iron protein: Defining the function of aspartate 129. Biochemistry 1995, 34, 10713-10723. [CrossRef] [PubMed]

54. Walker, G.A.; Mortenson, L.E. Effect of magnesium adenosine $5^{\prime}$-triphosphate on the accessibility of the iron of clostridial azoferredoxin, a component of nitrogenase. Biochemistry 1974, 13, 2382-2388. [CrossRef] [PubMed]

55. Ljones, T.; Burris, R.H. Nitrogenase: The reaction between iron protein and bathophenanthrolinedisulfonate as a probe for interactions with MgATP. Biochemistry 1978, 17, 1866-1872. [CrossRef] [PubMed]

56. Deits, T.L.; Howard, J.B. Kinetics of MgATP-dependent iron chelation from the Fe-protein of the Azotobacter vinelandii nitrogenase complex. Evidence for two states. J. Biol. Chem. 1989, 264, 6619-6628. [PubMed]

57. Anderson, G.L.; Howard, J.B. Reactions with the oxidized iron protein of Azotobacter vinelandii nitrogenase: Formation of a 2Fe center. Biochemistry 1984, 23, 2118-2122. [CrossRef] [PubMed]

58. Orme-Johnson, W.H.; Hamilton, W.D.; Jones, T.L.; Tso, M.-Y.W.; Burris, R.H.; Shah, V.K.; Brill, W.J. Electron paramagnetic resonance of nitrogenase and nitrogenase components from Clostridium pasteurianum W5 and Azotobacter vinelandii OP. Proc. Natl. Acad. Sci. USA 1972, 69, 3142-3145. [CrossRef] [PubMed]

59. Smith, B.E.; Lowe, D.J.; Bray, R.C. Studies by electron paramagnetic resonance on the catalytic mechanism of nitrogenase of Klebsiella pneumoniae. Biochem. J. 1973, 135, 331-341. [CrossRef] [PubMed]

60. Lindahl, P.A.; Gorelick, N.J.; Münck, E.; Orme-Johnson, W.H. EPR and Mössbauer studies of nucleotide-bound nitrogenase iron protein from Azotobacter vinelandii. J. Biol. Chem. 1987, 262, 14945-14953. [PubMed]

61. Yates, M.G. Biological Nitrogen Fixation; Stacey, G., Burris, R.H., Evans, H.J., Eds.; Chapman and Hall: New York, NY, USA, 1992; p. 685.

62. Hausinger, R.P.; Howard, J.B. Thiol reactivity of the nitrogenase Fe-protein from Azotobacter vinelandii. J. Biol. Chem. 1983, 258, 13486-13492. [PubMed]

63. Chen, L.; Gavini, N.; Tsuruta, H.; Eliezer, D.; Burgess, B.K.; Doniach, S.; Hodgson, K.O. MgATP-induced conformational changes in the iron protein from Azotobacter vinelandii, as studied by small-angle X-ray scattering. J. Biol. Chem. 1994, 269, 3290-3294. [PubMed] 
64. Willing, A.; Howard, J.B. Cross-linking site in Azotobacter vinelandii complex. J. Biol. Chem. 1990, 265, 6596-6599. [PubMed]

65. Willing, A.H.; Georgiadis, M.M.; Rees, D.C.; Howard, J.B. Cross-linking of nitrogenase components. Structure and activity of the covalent complex. J. Biol. Chem. 1989, 264, 8499-8503. [PubMed]

66. Wolle, D.; Dean, D.; Howard, J. Nucleotide-iron-sulfur cluster signal transduction in the nitrogenase iron-protein: The role of Asp125. Science 1992, 258, 992-995. [CrossRef] [PubMed]

67. Seefeldt, L.C. Docking of nitrogenase iron-and molybdenum-iron proteins for electron transfer and MgATP hydrolysis: The role of arginine 140 and lysine 143 of the Azotobacter vinelandii iron protein. Protein Sci. 1994, 3, 2073-2081. [CrossRef] [PubMed]

68. Chang, C.L.; Davis, L.C.; Rider, M.; Takemoto, D.J. Characterization of nifH mutations of Klebsiella pneumoniae. J. Bacteriol. 1988, 170, 4015-4022. [CrossRef] [PubMed]

69. Lowery, R.G.; Chang, C.L.; Davis, L.C.; McKenna, M.C.; Stevens, P.J.; Ludden, P.W. Substitution of histidine for arginine-101 of dinitrogenase reductase disrupts electron transfer to dinitrogenase. Biochemistry 1989, 28, 1206-1212. [CrossRef] [PubMed]

70. Yang, Z.-Y.; Ledbetter, R.; Shaw, S.; Pence, N.; Tokmina-Lukaszewska, M.; Eilers, B.; Guo, Q.; Pokhrel, N.; Cash, V.L.; Dean, D.R.; et al. Evidence that the $\mathrm{P}_{\mathrm{i}}$ release event is the rate-limiting step in the nitrogenase catalytic cycle. Biochemistry 2016, 55, 3625-3635. [CrossRef] [PubMed]

71. Tezcan, F.A.; Kaiser, J.T.; Howard, J.B.; Rees, D.C. Structural evidence for asymmetrical nucleotide interactions in nitrogenase. J. Am. Chem. Soc. 2015, 137, 146-149. [CrossRef] [PubMed]

72. Lanzilotta, W.N.; Parker, V.D.; Seefeldt, L.C. Thermodynamics of nucleotide interactions with the Azotobacter vinelandii nitrogenase iron protein. Biochim. Biophys. Acta Protein Struct. Mol. 1999, 1429, 411-421. [CrossRef]

(C) 2018 by the authors. Licensee MDPI, Basel, Switzerland. This article is an open access article distributed under the terms and conditions of the Creative Commons Attribution (CC BY) license (http:/ / creativecommons.org/licenses/by/4.0/). 